ISSN 1392-3196 / e-ISSN 2335-8947

Zemdirbyste-Agriculture, vol. 107, No. 3 (2020), p. 203-208

DOI $10.13080 /$ z-a.2020.107.026

\title{
Which land use is better suited to increase the fertility of ex-arable sandy soils?
}

\author{
Asta KAZLAUSKAITE-JADZEVICE ${ }^{1}$, Liudmila TRIPOLSKAJA ${ }^{1}$, \\ Jonas VOLUNGEVICIUS ${ }^{2}$, Eugenija BAKSIENE ${ }^{1}$ \\ ${ }^{1}$ Lithuanian Research Centre for Agriculture and Forestry, Vokè Branch \\ Žalioji 2, Vilnius, Lithuania \\ E-mail: asta.kazlauskaite-jadzevice@lammc.lt \\ ${ }^{2}$ Lithuanian Research Centre for Agriculture and Forestry, Institute of Agriculture \\ Instituto 1, Akademija, Kèdainiai distr., Lithuania
}

\begin{abstract}
The land surface of the European continent is dominated by loamy sand and sand, and soils of this texture are usually characterised by very low agronomic value. Land use change in coarse textured soils affects the agrochemical properties and helps to assess their impacts on soil fertility. The present study investigated the effects of conversion of arable soil to managed grassland, abandoned land and pine-afforested land on the agro-chemical properties of an Endocalcaric Cambic Arenosol.

In the temperate climatic zone, it is expedient to convert low-productivity soils into fertilised, managed grassland to stop soil degradation: during 21 years, $\mathrm{C}_{\text {org }}$ content increased by $15.7 \%$ in the A horizon and provided the opportunity to regulate soil nutrient elements and acidity. Abandoned land formation on arable land improved soil fertility: during 21 years, $\mathrm{C}_{\mathrm{org}}$ content increased by $24.4 \%$ in the A horizon, but $\mathrm{K}$ content in this horizon decreased due to the leaching. The establishment of pine-afforested land on sandy soil stimulated eluvial processes, increased soil acidity and decreased the amount of nutrients and organic carbon content.
\end{abstract}

Key words: available nutrients, land use conversion, organic carbon, soil acidity.

\section{Introduction}

Requirements for the rational use of land resources oblige the re-evaluation of the use of infertile soils for agricultural production. The preservation of soil fertility is especially relevant in light-textured soils, which are less resistant to the impacts of agrotechnical practices and the effects of climate change. In such soils, it is often appropriate to abandon agricultural activities and to change the land-use. However, land use change affects soil morphological, physical, chemical and biological properties, as it changes both the type of vegetation and the nature of the agrotechnical measures applied (Prokofeva, Poputnikov, 2010; Kalinina et al., 2013; Novikova, Konyushkova, 2013). Lv and Liang (2012) propose that by reducing the anthropogenic load and the intensity of the economic activity, due to agroecosystem self-regulation and prevailing zonal paedogenic processes, the soil partially regains its original condition, although it does not fully recover its natural properties. Signs of agrogenic activities in the soil profile can be recorded 100 years after the cessation of agrarian activities (Kalinina et al., 2009). Veenstra and Burras (2015) suggest that due to the application of agrotechnical operations, the variation in morphological and agro-chemical properties of the soil profile can reach a depth of up to 100-150 cm, although the largest changes are recorded in the upper $(0-30-45 \mathrm{~cm})$ soil layers.

When converting arable soil areas into other land uses, the impacts of the new land use on the prevention of soil fertility degradation and the possibility of obtaining economic benefits should be assessed. Agricultural land fertility is characterised by the following key indicators: the content of organic carbon, nutrient elements and acidity. The accumulation of organic carbon is closely related to the species composition of the vegetation and to soil morphological and agro-chemical properties (Kalinina et al., 2010). Soil acidity is an important indicator of agro-chemical properties in areas of excessive rainfall and determines the bioavailability of nutrient elements to plants and microorganisms, while influencing plant productivity and microbial activity (Wasak, Drewnink, 2015). Acidity is also directly related to parent material, climatic conditions and vegetation type (Gregory, Nortcliff, 2013). In this way, changes in soil properties after arable land conversion into other land

Please use the following format when citing the article:

Kazlauskaite-Jadzevice A., Tripolskaja L., Volungevicius J., Baksiene E. 2020. Which land use is better suited to increase the fertility of ex-arable sandy soils? Zemdirbyste-Agriculture, 107 (3): 203-208. DOI 10.13080/z-a.2020.107.026 
uses are determined by the interaction of anthropogenic and natural factors with various changes in soil properties in different climatic zones.

In this context, the aim of this study was to investigate the changes in agro-chemical properties of sandy soil of fluvioglacial origin after its conversion into other land uses: managed grassland, abandoned land and pine-afforested land.

\section{Materials and methods}

Study object and experimental site. Experimental site was arranged at the Lithuanian Centre for Agriculture

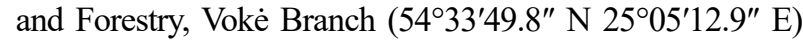
on an Endocalcaric Cambic Arenosol (WRB, 2014). The soil had formed on fluvioglacial deposits and had the following profile: Ap-AB-B1-B2-1C-C2. Carbonates were located at a depth of $80-100 \mathrm{~cm}$. The soil texture (by FAO) of the Ap horizon was determined by a pipette and sieve method and was as follows: sand $(63 \mu \mathrm{m}-2 \mathrm{~mm})$ $88.7-89.4 \%$, silt $(2-63 \mu \mathrm{m}) 8.2-8.8 \%$, clay $(<2 \mu \mathrm{m})$ $2.4-2.5 \%$ (Guidelines..., 2006). The study area is located in the temperate climate zone with a mean annual air temperature of $+6.0^{\circ} \mathrm{C}$ and mean annual precipitation of $664 \mathrm{~mm}$. Such a relationship between air temperature and precipitation determines soil moisture and leaching and is favourable for organic matter mineralisation.

The field experiment for studying the changes in soil properties after the conversion of arable land to other land uses was established in 1995. Up to 1995, this soil was considered as arable. The field experimental design includes three most relevant land uses in Europe: 1) managed grassland $\left(\mathrm{MG}_{\text {unfert }}-\right.$ unfertilised, $\mathrm{MG}_{\text {fert }}-$ fertilised with optimal rates of NPK), 2) abandoned land and 3) pine-afforested land. The total size of each land use site was $400 \mathrm{~m}^{2}(20 \times 20 \mathrm{~m})$. The managed grassland site was divided into two subplots - unfertilised and fertilised ones $\left(200 \mathrm{~m}^{2}\right.$ each). The land use conversion methodology used is currently the most recommended methodology to aid decision-making on environmental issues in Europe (Poeplau, Don, 2013) and the USA (Martens et al., 2003).

A grass-legume mixture was grown in the managed grassland site. During the period from 1995 to 2006, it included a hybrid lucerne (Medicago varia L.) and four grass species: red fescue (Festuca rubra L.), bromegrass (Bromus inermis Leyss.), cock'sfoot grass (Dactylis glomerata L.) and meadow-grass (Poa pratensis L.). In 2007, the grasses were reseeded and the same grass mixture was grown in 2007-2015, only cock's-foot was replaced by timothy (Phleum pratense $\mathrm{L}$.). The grasses were fertilised with $\mathrm{N}_{60} \mathrm{P}_{90} \mathrm{~K}_{120}$ and cut twice during the vegetation period. The mass of the phytocenosis was removed from the experimental area.

During the study period, a natural vegetation phytocenosis typical of sandy soils in this region was formed on the site of abandoned arable land. The botanical composition of the phytocenosis varied depending on the hydrothermal conditions of the growing season. In 1995, 39 plant species were established, while in 2015 - only 18. The dominant species were couch grass (Elytrigia repens L.), birds-foot trefoil (Lotus corniculatus L.), tall fescue (Festuca arundibances Schreb.), cock's-foot grass (Dactylus glomerata L.) and Canadian horseweed (Conyza canadiensis L.).
Scots pine (Pinus sylvestris L.) was grown in a site planted with pine trees during the study period. In 1995, 10,000 seedlings ha-1 were planted. After thinning in 2009 and in 2015, the tree density was 3,509 trees ha-1.

Soil sampling and analytical methods. Soil samples for the determination of agro-chemical indicators were taken before the experiment establishment in 1995 and in 2015. In 1995, the topsoil (0-25 cm) of the experimental area had similar agro-chemical properties. Four soil samples $(n=4)$ were taken from different land use sites $(20 \times 20 \mathrm{~m})$. Soil acidity $\left(\mathrm{pH}_{\mathrm{KCl}}\right)$ ranged from 6.0 to 6.8, plant-available phosphorus $\left(\mathrm{P}_{2} \mathrm{O}_{5}\right)$ - from 157 to 177 , potassium $\left(\mathrm{K}_{2} \mathrm{O}\right)$ - from 170 to $192 \mathrm{mg} \mathrm{kg}^{-1}$, organic carbon $\left(\mathrm{C}_{\mathrm{org}}\right)-9.5-9.9 \mathrm{~g} \mathrm{~kg}^{-1}$. In 2015, soil samples were taken in three replications from each land use site $(\mathrm{n}=$ 12). Further, for soil and plant sampling, each land use plot was divided into three replicates. Soil samples were collected using a stainless-steel cylindrical soil auger. The soil samples for analytical determinations were airdried, gently crushed and passed through a 2-mm mesh sieve. Soil bulk density was determined by the core method, using a metal ring pressed into the soil (intact core) and determining the weight after drying (McKenzie et al., 2004).

Soil agro-chemical properties were determined as follows: $\mathrm{pH}_{\mathrm{KCl}}$ - by ISO 10390:2005 potentiometric method ( $1 \mathrm{~mol} \mathrm{l}^{-1} \mathrm{KCl}$ suspension, soil and solution ratio $1: 2.5) ; \mathrm{C}_{\text {org }}$ - ISO 10694:1995 (determination of $\mathrm{C}_{\text {org }}$ after dry combustion; Dumas method); plant-available $\mathrm{P}_{2} \mathrm{O}_{5}$ and $\mathrm{K}_{2} \mathrm{O}$ - Egner-Riehm-Domingo (A-L) method (ammonium lactate extraction).

In the A horizon soil organic carbon (SOC) stocks were calculated as follows (Poeplau et al., 2017):

$\mathrm{SOC}\left(\mathrm{Mg} \mathrm{ha}^{-1}\right)=\mathrm{SOC}_{\text {conc }} \times \mathrm{BD}_{\text {sample }} \times$ depth $\div 10$,

where $\mathrm{SOC}_{\text {conc }}$ is the soil organic carbon concentration $\left(\mathrm{g} \mathrm{kg}^{-1}\right), \mathrm{BD}_{\text {sample }}$ - the bulk density of the total sample $\left(\mathrm{t} \mathrm{m}^{-3}\right)$, depth - the thickness of the soil A horizon $(\mathrm{cm}), 10$ - coefficient to calculate SOC stocks $\left(\mathrm{Mg} \mathrm{ha}^{-1}\right)$.

Statistical analysis. The experimental data were evaluated by analysis of variance (ANOVA), using the Fisher's least significant difference as post-hoc test. The probability level was set at 0.05 . Duncan's post-hoc test was used to carry out multiple comparisons. Standard error (SE) values were used to estimate the deviations of agro-chemical parameters from the mean values (Clewer, Scarisbrick, 2001).

\section{Results and discussion}

Organic carbon $\left(\boldsymbol{C}_{\text {org }}\right)$. At the beginning of the experiment, the $\mathrm{C}_{\text {org }}$ content in the soil A horizon were similar for all sites and amounted to $9.5-9.9 \mathrm{~g} \mathrm{~kg}^{-1}$ (Fig. 1A). The conversion of arable land into other landuses changed the ratio of plant residue humification and mineralisation processes in the soil as well as the rate of accumulation of new humic substances.

Land use change of arable land to managed grassland had various impacts on the accumulation of $\mathrm{C}_{\text {org }}$, which depended on fertilisation. In the soil of grassland without fertiliser use over a period of 21 years, the amount of $\mathrm{C}_{\text {org }}$ slightly decreased from 9.9 to $9.4 \mathrm{~g} \mathrm{~kg}^{-1}$ $\left(F_{\text {fact. }}>F_{\text {theor. }}\right)$. Therefore, the mineralisation of organic matter in the soil was more distinct in comparison with 


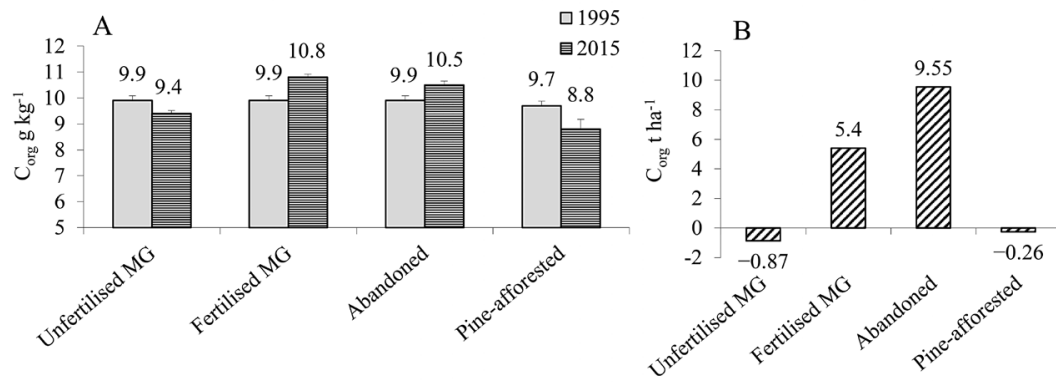

$\mathrm{MG}$ - managed grassland

Figure 1. Changes in the organic carbon $\left(\mathrm{C}_{\text {org }}\right)$ amount $(\mathrm{A})$ and stocks $(\mathrm{B})$ in the soil Ap horizon

the formation of humic substances from the postharvest residues and the dead root systems. Grassland fertilisation with mineral $\mathrm{N}_{60} \mathrm{P}_{90} \mathrm{~K}_{120}$ increased herbage yields and thus $\mathrm{C}_{\text {org }}$ accumulation in the soil. Throughout the 21 years, the amount of $\mathrm{C}_{\text {org }}$ in the upper layer increased by $0.9 \mathrm{~g} \mathrm{~kg}^{-1}$, or $43 \mathrm{mg} \mathrm{kg}^{-1} \mathrm{yr}^{-1}\left(F_{\text {fact. }}>F_{\text {theor. }}\right)$.

Previous studies (Stypinski, Mastalerczuk, 2006; Barančiková et al., 2016; Kämpf et al., 2016) have reported that grassland phytocenoses are characterised by carbon accumulation in the soil. De Deyn et al. (2009) found that $\mathrm{C}_{\text {org }}$ is more intensively accumulated in the soil, when several grass species are grown and their functional group ratio is important for the conservation of $\mathrm{C}_{\text {or }}$ stocks in grassland soils. In this experiment, a mixture of hybrid lucerne and four highly productive grasses was cultivated; however, an increase in the content of $\mathrm{C}_{\text {org }}$ in the A horizon was established only in the fertilised soil. It should be noted that in the soil of a grassland older than 21 years, A horizon thickness increased by $2 \mathrm{~cm}$ in the unfertilised soil and by $4 \mathrm{~cm}$ in the fertilised soil. In spite of an increase in A horizon thickness, the stocks of $\mathrm{C}_{\text {or }}$ in the soil of the unfertilised grassland decreased only by $0.87 \mathrm{t} \mathrm{ha}^{-1}$, while in the soil of the fertilised grassland they increased by $5.40 \mathrm{t} \mathrm{ha}^{-1}$, or $257 \mathrm{~kg} \mathrm{ha}^{-1} \mathrm{yr}^{-1}$ (Fig. 1B). This difference was determined by a better-developed root system and a larger aboveground mass in the soil fertilised with NPK fertilisers (Katterer et al., 2012; Lal, 2013). Fornara and Tilman (2008) suggest that $C_{\text {org }}$ accumulation in a grassland phytocenosis depends on the biomass of the root system, and the combination of the main grasses and legumes $\left(\mathrm{C}_{4}\right.$-type plants) facilitates its accumulation increase in the soil.

A similar increase $(+4 \mathrm{~cm})$ in humus horizon thickness of the soil was established also on the abandoned land site. In the soil, the $\mathrm{C}_{\text {org }}$ amount also considerably $\left(+0.6 \mathrm{~g} \mathrm{~kg}^{-1}\right)$ increased $\left(\stackrel{\mathrm{org}}{F_{\text {fact. }}}>F_{\text {theor }}\right)$. Although vegetation of a significantly lower productivity (LSD $16.59, P<0.05)$ is naturally formed in abandoned land $\left(24.8 \mathrm{GJ} \mathrm{ha}^{-1} \mathrm{yr}^{-1}\right)$ compared to unfertilised managed grassland (54.7 GJ ha' $\mathrm{yr}^{-1}$ ). The aboveground part is not removed from the field and at the end of the growing season plant residues are mineralised on the soil surface. This determines a higher $\mathrm{C}_{\text {org }}$ accumulation in the soil $\mathrm{A}$ horizon as compared to unfertilised managed grassland $(P<0.05)$. In the abandoned land soil, on average, the $\mathrm{C}_{\text {org }}$ amount increased by $29 \mathrm{mg} \mathrm{kg}^{-1} \mathrm{yr}^{-1}$ and stocks by $460 \mathrm{t} \mathrm{ha}^{-1} \mathrm{yr}^{-1}$, i.e. by $24.4 \%$ in the A horizon over 21 years. Zhang et al. (2012) have found that the rate of $\mathrm{C}_{\text {org }}$ accumulation in a plant phytocenosis depends on the herbaceous species. According to their data, conversion of arable land into natural fallow land resulted in a $\mathrm{C}_{\text {org }}$ reserve increase by $5.1 \%$ in the $0-20-\mathrm{cm}$ soil layer over 6 years, and when the arable land was sown with cultivated grasses and subsequently transformed into fallow land, the $\mathrm{C}_{\text {org }}$ reserves increased by $22.6 \%$.

The afforestation of low-productivity soils substantially changes the carbon cycle within the ecosystem. Carbon accumulation content in the tree biomass and $\mathrm{C}_{\text {org }}$ stocks in the soil are replenished at the expense of carbon from microbiota and tree debris. The role of the root system in the carbon accumulation process within the forest ecosystem decreases. According to the experimental data, 21 years following arable land transformation to pine-afforestation, the $\mathrm{C}_{\text {rg }}$ amount in the A horizon of sandy soil decreased by $0.9 \mathrm{~g} \mathrm{~kg}^{-1}\left(F_{\text {fact }}\right.$ $>F_{\text {tehor. }}$ ); however, its thickness increased by $3 \mathrm{~cm}$.

Compared to the abandoned land and unfertilised managed grassland, the mineralisation of organic matter in pine-afforested land was higher. Over the 21-year period, $\mathrm{C}_{\text {org }}$ amount in the soil $\mathrm{A}$ horizon decreased by $10.2 \%$, but the $\mathrm{C}_{\text {org }}$ stocks only by $1.0 \%\left(-12.4 \mathrm{~kg} \mathrm{ha}^{-1}\right.$ $\left.\mathrm{yr}^{-1}\right)$. Similar data have been published by Zhiyanski et al. (2016), who found that afforestation with coniferous tree species allowed the accumulation and preservation of soil $\mathrm{C}_{\text {org }}$ stocks, but even several decades after the conversion from arable land to forest areas this effect was expressed only weakly and did not compensate for the $\mathrm{C}_{\text {org }}$ losses due to previous active cultivation. It is maintained that the accumulation of $\mathrm{C}_{\text {org }}$ in a grassland phytocenosis was accelerated due to the abundant and well-developed grass root system (Wei et al., 2012; Conant et al., 2017). Barcena et al. (2014) specify that $\mathrm{C}_{\text {org }}$ accumulation in coniferous forests depends on the renaturalisation period. In young (up to 30-years old) forests, a decrease in the volume of organic matter stocks in the soil is observed, while an increase is observed in more mature forests. This is associated with the amount of debris, which depends on the age of the trees and on their biochemical composition.

Content of plant-available phosphorus $\left(\mathrm{P}_{2} \mathrm{O}_{8}\right)$ and potassium $\left(\boldsymbol{K}_{2} \boldsymbol{O}\right)$. Changes in plant-available $\mathrm{P}_{2} \mathrm{O}_{5}$ and $\mathrm{K}_{2} \mathrm{O}$ content in the soil after the conversion of arable land to other land-uses depend on the fertilisation with $\mathrm{P}$ and $\mathrm{K}$ fertilisers, the productivity of plants and the leaching of these elements. Over the 21-year period, the amount of plant-available $\mathrm{P}_{2} \mathrm{O}_{5}$ in the $\mathrm{A}$ horizon in the unfertilised managed grassland decreased by $93 \mathrm{mg} \mathrm{kg}^{-1}$ $\mathrm{P}_{2} \mathrm{O}_{5}\left(4.43 \mathrm{mg} \mathrm{kg}^{-1} \mathrm{yr}^{-1}\right)\left(F_{\text {fact }}>F_{\text {theor }}\right)$, while that of $\mathrm{K}_{2} \mathrm{O}$ decreased by $113 \mathrm{mg} \mathrm{kg}^{-1} \mathrm{~K}_{2} \mathrm{O}\left(5.38 \mathrm{mg} \mathrm{kg}^{-1} \mathrm{yr}^{-1}\right)\left(F_{\text {fact. }}>\right.$ $F_{\text {theor. }}$ ) (Table).

In the fertilised soil with a positive $\mathrm{P}$ balance $\left(+30.7 \mathrm{~kg} \mathrm{ha}^{-1} \mathrm{yr}^{-1}\right), \mathrm{P}$ accumulation was observed, and 
Table. Changes in plant-available phosphorus $\left(\mathrm{P}_{2} \mathrm{O}_{5}\right)$ and potassium $\left(\mathrm{K}_{2} \mathrm{O}\right)$ amount in the soil A horizon

\begin{tabular}{lcccc}
\hline & \multicolumn{3}{c}{$\mathrm{P}_{2} \mathrm{O}_{5}$} & \multicolumn{2}{c}{$\mathrm{K}_{2} \mathrm{O}$} \\
\cline { 2 - 5 } \multicolumn{1}{c}{ Land use } & \multicolumn{2}{c}{$\mathrm{mg} \mathrm{kg}^{-1}$} \\
\cline { 2 - 5 } & 1995 & 2015 & 1995 & 2015 \\
\hline Fertilised managed grassland & $177 \pm 4.9$ & $210 \mathrm{~d}$ & $174 \pm 4.7$ & $99 \mathrm{~b}$ \\
Unfertilised managed grassland & $177 \pm 4.9$ & $84 \mathrm{a}$ & $174 \pm 4.7$ & $61 \mathrm{a}$ \\
Abandoned land & $157 \pm 4.9$ & $171 \mathrm{c}$ & $170 \pm 4.7$ & $123 \mathrm{c}$ \\
Pine-afforested land & $168 \pm 4.9$ & $126 \mathrm{~b}$ & $192 \pm 4.7$ & $96 \mathrm{~b}$ \\
\hline
\end{tabular}

Note. Data expressed as means \pm standard error; means in a column followed by different letters are significantly different $(P<0.05)$.

after 21 years the amount of plant-available $\mathrm{P}_{2} \mathrm{O}_{5}$ had increased by $33 \mathrm{mg} \mathrm{kg}^{-1}\left(1.57 \mathrm{mg} \mathrm{kg}^{-1} \mathrm{yr}^{-1}\right)\left(F_{\text {fact. }} \stackrel{2}{>} F_{\text {theor. }}\right)$. Potassium content decreased both in the fertilised and unfertilised soils, although $\mathrm{K}$ incorporated together with fertilisers completely compensated for its amount removed with herbage yield (balance $+8.7 \mathrm{~kg} \mathrm{ha}^{-1} \mathrm{yr}^{-1}$ ). Most likely, the decreased $\mathrm{K}$ content in the soil is associated with its more intensive leaching from fertilised grassland soil. A consistent accumulation of $\mathrm{P}$ occurred in the abandoned land site during the 21-year period with an increase by $14 \mathrm{mg} \mathrm{kg}^{-1}\left(F_{\text {fact. }}>F_{\text {theor. }}\right)$. Plants, absorbing $\mathrm{P}$ from deeper soil layers, accumulated it in the aboveground parts, which were mineralised into plant-available $\mathrm{P}_{2} \mathrm{O}_{5}$ compounds and accumulated in the upper A horizon. A similar process took place with $\mathrm{K}$ compounds; however, due to a weaker $\mathrm{K}$ sorption in sandy soils, the amount of plant-available $\mathrm{K}_{2} \mathrm{O}$ decreased to $47 \mathrm{mg} \mathrm{kg}^{-1}$ ( $F_{\text {fact. }}>$ $F_{\text {theor. }}$ ) over the 21-year period.

During the study period, the plant-available $\mathrm{P}_{2} \mathrm{O}_{5}$ amount in the soil A horizon of the site planted with pine trees decreased by $42 \mathrm{mg} \mathrm{kg}^{-1}\left(F_{\text {fact. }}>F_{\text {theor. }}\right)$, while the amount of plant-available $\mathrm{K}_{2} \mathrm{O}$ decreased even more - by $96 \mathrm{mg} \mathrm{kg}^{-1}\left(F_{\text {fact. }}>F_{\text {theor. }}\right)$, mainly because $\mathrm{P}$ and $\mathrm{K}$ accumulated in the tree biomass were not returned to the soil, as is the case with the mineralisation of the biomass of abandoned land.

Based on the results of current study, changes in the soil properties after arable land conversion into other land-uses on sandy soil are dependent on fertilisation, the type of land use and the sorption of elements in the soil. The establishment of unfertilised managed grassland and pine-afforestation in arable soils accelerated A horizon degradation. After 21 years, the amount of plant-available $\mathrm{K}_{2} \mathrm{O}$ in the soil of these land-uses decreased to 49 $96 \mathrm{mg} \mathrm{kg}^{-1}$. The amount of plant-available $\mathrm{P}_{2} \mathrm{O}_{5}$, which is characterised by strong sorption ability, only decreased to $84 \mathrm{mg} \mathrm{kg}^{-1}$ in unfertilised managed grassland.

Soil acidity $\left(\mathbf{p H}_{K C}\right)$. The conversion from arable land to other land-uses had a strong but uneven influence on soil acidification processes. As a result of the earlier applied periodic liming, the $\mathrm{pH}_{\mathrm{KCl}}$ of the upper A layer in the experimental sites was 6.0-6.8. The establishment of managed grassland, whose sward was formed of hybrid lucerne and four other grasses, accelerated the acidification of the A horizon, and over the period of 21 years the $\mathrm{pH}$ decreased by 0.7 units $(-0.03$ units per year) in the unfertilised site and by 1.9 units $(-0.09$ units per year) $(P<0.05)$ in the site fertilised with $\mathrm{N}_{60} \mathrm{P}_{90} \mathrm{~K}_{120}$ (Fig. 2).

The different rates of acidification in unfertilised and fertilised soils were determined by the differences in $\mathrm{Ca}$ and $\mathrm{Mg}$ accumulation in the herbage. The herbage yield in the fertilised site was 1.71 times higher compared

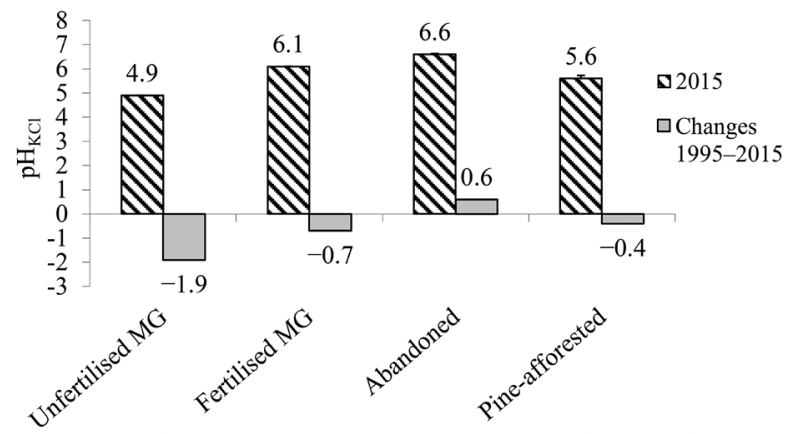

MG - managed grassland

Figure 2. Changes in soil acidity $\left(\mathrm{pH}_{\mathrm{KCl}}\right)$ in the A horizon

to that of the unfertilised site; consequently, the removal of $\mathrm{Ca}$ and $\mathrm{Mg}$ with plant biomass was higher, resulting in changes in the $\mathrm{pH}$. Harvesting reduced the amount of $\mathrm{Ca}$ and $\mathrm{Mg}$ with annual biomass of phytocenose: by on average $68.7 \mathrm{~kg} \mathrm{ha}^{-1} \mathrm{Ca}$ and $8.9 \mathrm{~kg} \mathrm{ha}^{-1} \mathrm{Mg}$ on the fertilized site and by on average $38.8 \mathrm{~kg} \mathrm{ha}^{-1} \mathrm{Ca}$ and $6.8 \mathrm{~kg} \mathrm{ha}^{-1} \mathrm{Mg}$ on the unfertilized site. The acidification of the humus horizon was also associated with $\mathrm{Ca}$ leaching with atmospheric precipitation. On average, in Arenosol, the losses of $\mathrm{Ca}$ due to leaching amounted to $259 \mathrm{~kg} \mathrm{ha}^{-1}$ $\mathrm{yr}^{-1}$ (Management of agoecosystem..., 2010). However, in grassland, such losses might have been influenced by the sward age. It has been established that with sward aging and depending on the amount of legumes, Ca leaching can increase from $15-22 \mathrm{~kg} \mathrm{ha}^{-1}$ during the first year of grass cultivation to $92-104 \mathrm{~kg} \mathrm{ha}^{-1}$ during the fourth year of cultivation (Semyonov, Muromtsev, 2006).

In this experiment, grasses were grown for 10 years without reseeding and this could have increased $\mathrm{Ca}$ and $\mathrm{Mg}$ leaching and, accordingly, accelerated soil A horizon acidification. The experimental results show that the establishment of managed grassland in arable soils, whose acidity had been reduced by periodic liming, increased acidification processes. To avoid degradation of soils, it is necessary to monitor their properties and to apply appropriate agrotechnical measures.

The opposite changes in soil acidity occurred due to the renaturalisation of arable land, its abandonment and leaving it as abandoned land. Over the course of 21 years, the $\mathrm{pH}$ of the A horizon in the abandoned land decreased from 6.0 to 6.6 units $\left(+0.03\right.$ units per year) $\left(F_{\text {fact. }}\right.$ $\left.\geq F_{\text {theor }}\right)$. Unlike in managed grassland, the aboveground part of the plants growing in abandoned land was not removed and, after the end of the growing season, the plant residues were deposited and mineralised on the soil surface, releasing the base elements that accumulated in the humus horizon and reduced its acidity. For the period of 21 years, $149 \mathrm{~kg} \mathrm{ha}^{-1} \mathrm{Ca}$ and $56 \mathrm{~kg} \mathrm{ha}^{-1} \mathrm{Mg}$ were accumulated per year in the abandoned site biomass. 
Pine-afforestation in arable soils accelerated the acidification of the A horizon and decreased the acidity by $0.4 \pm 0.12 \mathrm{pH}$ units $\left(F_{\text {fact. }}>F_{\text {theor. }}\right)$ over the course of 21 years $(+0.02 \mathrm{pH}$ units per year). Soil acidification is determined by three factors: the absorption of $\mathrm{Ca}$ and $\mathrm{Mg}$ by growing pine trees, their leaching with atmospheric precipitation and the organic acids formed during the decomposition of pine tree debris. According to Yesilonis et al. (2016), the acidity of the soil and content of $\mathrm{Ca}$ and $\mathrm{Mg}$ depend on the forest age, with young soils having higher $\mathrm{Mg}$ and $\mathrm{Ca}$ content and higher $\mathrm{pH}$ values. Kalinina et al. (2013) showed that 17 years following the establishment of a natural coniferous forest resulted in a decrease in soil acidity by as much as $1.9 \mathrm{pH}$ units. Similar data regarding the effect of afforestation on soil acidity have been reported by Holubík et al. (2014) and Mostovaya et al. (2015).

Thus, the conversion from arable to afforested land in sandy soils stimulates eluvic processes in the subsoil and prevents the stabilisation of $\mathrm{C}_{\text {org }}$. These are zonal paedogenic processes in cool, humid areas and characterise the initial renaturalisation processes of agrogenic soils.

\section{Conclusions}

1. In the temperate climate zone of Eastern Europe, it is expedient to convert arable, low-productivity land, characterised by weak sorption and soil water storage capacity into fertilised managed grasslands. This land use can stop the degradation of soil fertility: increased organic carbon $\left(\mathrm{C}_{\mathrm{org}}\right)$ accumulation by $15.4 \%$ over the course of 21 years in the A horizon regulated nutrient content and soil acidity.

2. The conversion of arable land into natural abandoned land stimulated $\mathrm{C}_{\text {org }}$ sequestration by $24.4 \%$ during 21 years in the A horizon and stabilised acidification processes, but reduced the content of plantavailable $\mathrm{K}_{2} \mathrm{O}$. This land use is ecologically efficient, albeit economically unprofitable.

3. The establishment of pine-afforestation areas in arable land on an Endocalcaric Cambic Arenosol accelerated eluvial processes that stimulated soil degradation, resulting in increased acidity and decreased amount of basic nutrients ( $\mathrm{P}$ and $\mathrm{K})$, basic elements $(\mathrm{Ca}$ and $\mathrm{Mg}$ ) and $\mathrm{C}_{\text {org }}$ stocks.

\section{Acknowledgements}

The paper presents research findings, obtained through the long-term research programme "Biopotential and quality of plants for multifunctional use" implemented by the Lithuanian Research Centre for Agriculture and Forestry. The authors thank Dr. M. Petrovas for the development of the experimental technique (1994) and performance of the experiment until 2001, and Dr. S. Marcinkonis for performance of the experiment during the period 2002-2012.

Received 11112019

Accepted 22042020

\section{References}

1. Barančiková G., Makovniková J., Halas J. 2016. Effect of land use change on soil organic carbon. Agriculture (Pol'nohospodarstvo), 62 (1): 10-18.

https://doi.org/10.1515/agri-2016-0002

2. Barcena T. G., Kier L. P., Vesterdal L., Stefansdottir H. M., Gundersen P., Sigurdsson B. D. 2014. Soil carbon stock change following afforestation in Northern Europe: a meta-analysis. Global Change Biology, 18: 2393-2405. https://doi.org/10.1111/gcb.12576

3. Clewer A. G., Scarisbrick D. H. 2001. Practical statistics and experimental design for plant and crop science. Wiley, $332 \mathrm{p}$.

4. Conant R. T., Cerri C. E. P., Osborne B. B., Paustian K. 2017. Grassland management impacts on soil carbon stocks: a new synthesis. Ecological Applications, 27: 662-668. https://doi.org/10.1002/eap.1473

5. De Deyn G. B., Quirk H., Yi Z., Oakley S., Ostle N. J., Bardgett R. D. 2009. Vegetation composition promotes carbon and nitrogen storage in model grassland communities of contrasting soil fertility. Journal of Ecology, 97 (5): 864-875.

https://doi.org/10.1111/j.1365-2745.2009.01536.x

6. Fornara D. A., Tilman D. 2008. Plant functional composition in influences rates of soil carbon and nitrogen accumulation. Journal of Ecology, 96: 314-322.

https://doi.org/10.1111/j.1365-2745.2007.01345.x

7. Gregory P. J., Nortcliff S. (eds). 2013. Soil conditions and plant growth. Wiley-Blackwell, p. 51-52. https://doi.org/10.1002/9781118337295

8. Guidelines for soil description. 2006. FAO, $109 \mathrm{p}$.

9. Holubík O., Podrázský V., Vopravil J., Khel T., Remeš J. 2014. Effect of agricultural lands afforestation and tree species composition on the soil reaction, total organic carbon and nitrogen content in the uppermost mineral soil profile. Soil and Water Research, 9: 192-200. https://doi.org/10.17221/104/2013-SWR

10. Kalinina O., Goryachkin S. V., Karavaeva N. A., Lyuri D. I., Najdenko L., Giani L. 2009. Self-restoration of post-agrogenic sandy soils in the southern Taiga of Russia: soil development, nutrient status, and carbon dynamics. Geoderma, 152 (1-2): 35-42. https://doi.org/10.1016/j.geoderma.2009.05.014

11. Kalinina O., Goryachkin S. V., Krause S.-E., Lyuri D. I., Giani L. 2010. Chronosequential alterations of properties of post-agrogenic Chernozems of the Kursk steppe zone of Russia under self-restoration. Proceedings of the $19^{\text {th }}$ World Congress of Soil Science, Soil Solutions for a Changing World. Brisbane, Australia. p. 21-24. https:// iuss.org/19th\%20WCSS/Symposium/pdf/0091.pdf

12. Kalinina O., Chertov O., Dolgikh A. V., Goryachkin S. V., Lyuri D. I., Vormstein S., Giani L. 2013. Self-restoration of post-agrogenic Albeluvisols: soil development, carbon stocks and dynamics of carbon pools. Geoderma, 207-208: 221-233. https://doi.org/10.1016/j.geoderma.2013.05.019

13. Kämpf I., Hölzel N., Störrle M., Broll G., Kiehl K. 2016. Potential of temperate agricultural soils carbon sequestration: a meta-analysis of land-use effects. Science of the Total Environment, 566-567: 428-435. https://doi.org/10.1016/j.scitotenv.2016.05.067

14. Katterer T., Bolinder M. A., Berglund K., Kirchmann H. 2012. Strategies for carbon sequestration in agricultural soil in northern Europe. Acta Agriculturae Scandinavica, Section A: Animal Science, 62 (4): 181-198. https://doi.org/10.1080/09064702.2013.779316

15. Lal R. 2013. Soil carbon management and climate change. Carbon Management, 4 (4): 439-462. https://doi.org/10.1007/978-3-319-04084-4 35

16. Lv H., Liang Z. 2012. Dynamics of soil organic carbon and dissolved organic carbon in Robina pseudoacacia forests. Journal of Soil Science and Plant Nutrition, 12 (4): 763-774. https://doi.org/10.4067/S0718-95162012005000030

17. Management of agoecosystem components. Results of long-term agrochemical experiments. $2010 /$ compiled by Tripolskaja L. et al. Lithuanian Research Centre for Agriculture and Forestry, p. 282-303. 
18. Martens D. A., Reedy T. R., Lewis D. T. 2003. Soil organic carbon content and composition of 130-year crop, pasture and forest land-use managements. Global Change Biology, 10: $65-78$. https://doi.org/10.1046/j.1529-8817.2003.00722.x

19. McKenzie N. J., Jacquier D. J., Isbell R. F., Brown K. L. 2004. Australian soils and landscapes: an illustrated compendium. https://doi.org/10.1071/9780643100732

20. Mostovaya A. S., Kurganova I. N., Lopes De Gerenyu V. O ., Khokhlova O. S., Rusakov A. V., Shapovalov A. S. 2015. Changes in the microbial activity of gray forest soils during the natural reforestration. Proceedings of Voronezh State University. Series: Chemistry. Biology. Pharmacy, 2: 64-72 (in Russian).

21. Novikova A. F., Konyushkova M. V. 2013. Anthropogenic transformation of soils in the northern Ergeni Upland (studies at the first experimental plot of the Arshan'Zelmen Research Station). Eurasian Soil Science, 46 (3): 241-253. https://doi.org/10.1134/S106422931303006X

22. Poeplau C., Don A. 2013. Sensitivity of soil organic carbon stocks and fractions to different land-use changes across Europe. Geoderma, 192: 189-201. https://doi.org/10.1016/j.geoderma.2012.08.003

23. Poeplau C., Vos C., Don A. 2017. Soil organic carbon stocks are systematically overestimated by misuse of the parameters bulk density and rock fragment content. Soil, 3: 61-66. https://doi.org/10.5194/soil-3-61-2017

24. Prokofeva T. V., Poputnikov V. O. 2010. Anthropogenic transformation of soils in the Pokrovskoe-Streshnevo Park (Moscow) and adjacent residential areas. Eurasian Soil Science, 43 (6): 701-711. https://doi.org/10.1134/S1064229310060116

25. Semyonov N. A., Muromtsev N. A. 2006. Influence of the plowed turf on grasses productivity and infiltration losses of chemical elements. Bulletin of V. V. Dokuchaev Soil Science Institute, 58: 39-44 (in Russian).
26. Stypinski P., Mastalerczuk G. 2006. Carbon sequestration by Polish grassland biomass. Grassland Science in Europe: Sustainable Grassland Productivity, 11: 763-765.

27. Veenstra J. J. Burras C. L. 2015. Soil profile transformation after 50 years of agricultural land use. Soil Science Society of America Journal, 79 (4): 1154-1162. https://doi.org/10.2136/sssaj2015.01.0027

28. Wasak K., Drewnik M. 2015. Land use effects on soil organic carbon sequestration in calcareous Leptosols in former pastureland - a case study from the Tatra Mountains (Poland). Solid Earth, 6: 1103-1115. https://doi.org/10.5194/se-6-1103-2015

29. Wei J., Cheng J., Li W., Liu W. 2012. Comparing the effect of naturally restored forest and grassland on carbon sequestration and its vertical distribution in the Chinese Loess Plateau. PLoS ONE, 7 (7): e40123: 1-8. https://doi.org/10.1371/journal.pone.0040123

30. WRB. 2014. World reference base for soil resources. World Soil Resources Reports No. 106, FAO, p. 187-189.

31. Yesilonis I., Szlavecz K., Pouyat R., Whigham D., Xia L. 2016. Historical land use and stand age effects on forest soil properties in the Mid-Atlantic US. Forest Ecology and Management, 370: 83-92. https://doi.org/10.1016/j.foreco.2016.03.046

32. Zhang L., Xie Z., Zhao R., Wang Y. 2012. The impact of land use change on soil organic carbon and labile organic carbon stocks in the Longzhong region of Loess Plateau. Journal of Arid Land, 4 (3): 241-250. https://doi.org/10.3724/SP.J.1227.2012.00241

33. Zhiyanski M., Glushkova M., Ferezliev A., Menichetti L., Leifeld J. 2016. Carbon storage and soil property changes following afforestation in mountain ecosystems of the Western Rhodopes, Bulgaria. iForest - Biogeosciences and Forestry, 9 (4): 626-634. https://doi.org/10.3832/ifor1866-008

ISSN 1392-3196 / e-ISSN 2335-8947

Zemdirbyste-Agriculture, vol. 107, No. 3 (2020), p. 203-208

DOI 10.13080/z-a.2020.107.026

\title{
Kuri žemėnauda labiau didina buvusių ariamų smèlžemiụ derlingumą?
}

\author{
A. Kazlauskaitè-Jadzevičè $\dot{e}^{1}$, L. Tripolskaja ${ }^{1}$, J. Volungevičius², E. Bakšienè ${ }^{1}$ \\ ${ }^{1}$ Lietuvos agrarrinių ir miškų mokslų centro Vokès filialas \\ ${ }^{2}$ Lietuvos agrarrinių ir miškų mokslų centro Žemdirbystès institutas
}

\section{Santrauka}

Visame Europos žemyno paviršiuje dominuoja priesmèlis, o šios granuliometrinès sudèties dirvožemiai dažniausiai yra labai mažos agronominés vertès. Stambios granuliometrinės sudèties dirvožemyje žemėnaudos kaita lemia jo cheminių savybių pokyčius ir padeda ịvertinti jụ ịtaką dirvožemio derlingumui. Tyrimo metu analizuotas ariamojo smèlžemio agrocheminių savybių pokytis, jo naudojimo būdą keičiant i kultūines pievas, apleistas žemes ir pušyną.

Nustatyta, kad vidutinio klimato zonoje nederlingus dirvožemius tikslinga paversti kultūrinèmis pievomis. Toks žeménaudos būdas padeda stabdyti dirvožemio degradaciją: per 21 metus A horizonte organinès anglies $\left(\mathrm{C}_{\text {org }}\right)$ kiekị padidino 15,7 \%. Jis suteikia galimybę reguliuoti dirvožemio mitybos elementų kiekị ir rūgštumo lygị. Apleisti žemès plotai buvusioje ariamoje žemejje pagerino dirvožemio derlingumą ir per 21 metus A horizonte $\mathrm{C}_{\text {org }}$ kieki padidino $24,4 \%$, tačiau dẻl išplovimo šiame horizonte sumažèjo kalio (K) kiekis. Miško priesmėlyje auginamos pušys stimuliuoja eliuvinius procesus, didina dirvožemio rūgštumą, mažina mitybos medžiagų koncentraciją ir organinès anglies kiekị.

Reikšminiai žodžiai: dirvožemio rūgštumas, judrieji elementai, organinė anglis, žemėnaudos konversija. 